\title{
DETERMINATION OF MANNING ROUGHNESS COEFFICIENT FOR BORDER IRRIGATION SYSTEM
}

\author{
M. A. Kassem* and M. I. Ghonimy**
}

\begin{abstract}
Manning roughness coefficient " $n$ " is one of the most important factors affecting the border irrigation design. The purpose of this study is to determine the Manning roughness coefficient values " $n$ " for border irrigation in a clay loam soil with compacted and uncompacted soil under continuous and surge flow. The determination was based on the volume balance equation in the form of a differential equation that was solved with the forward finite difference. The results indicated that, soil surface compaction had its effect on $n$ values of the first irrigation and had not any effect for the next irrigations. For continuous flow, at first irrigation, the values of $n$ were 0.1915 and 0.164 for un-compacted and compacted soils respectively. At the second irrigation, the $n$ values decreased by about $44.51 \%$ and $49.82 \%$ compared to the first irrigation for compacted and un-compacted soil respectively. However, after the second irrigation, the seedling of wheat resulted on increases the $n$ values. The minimum value, 0.083, of $n$ was achieved at the second irrigation for surge flow. While, the maximum value, 0.25, of $n$ was found at the seventh irrigation for continuous flow. Also, by using surge flow, the $n$ values were decreased compared with those for continuous flow without vegetation crop or with wheat crop.
\end{abstract}

\section{INTRODUCTION}

$\mathrm{O}$ ne of the most important parameters that affect the water flow in surface irrigation is the resistance that occurs in the soil surface. The resistance due to uneven soil surface at the bottom of the border is shear stress while the resistance due to material and vegetation is drag force (Trout, 1992). All of these forces act in the opposite direction to flow and reduce the flow velocity.

\footnotetext{
* Assoc. Prof., Ag. Eng. Dept., Fac. of Ag., Cairo Univ. ** Prof., Ag. Eng. Dept., Fac. of Ag., Cairo Univ.
} 
The effects of these resistances in the surface irrigation are combined to form a resistance factor referred to as the Manning roughness coefficient $" n "$ (Gilley and Finkner, 1991). The Manning roughness coefficient is dependent on different factors such as crop vegetation in the border, mean slope of the border soil surface and inflow rates of water (Trout, 1992). These factors should be considered in estimating the value of " $n "$ for designing border irrigation. The Manning roughness coefficient " $n$ " is one of the parameters in designing the border irrigation for efficient water application in the field (Valiantzas, 1994). Sepaskhah and Bondar (2002) found that the calculated $n$ value for different irrigations was decreased from the first to the third irrigations for bare border irrigation. Bakery et al. (1992) mentioned that the percentage of vegetation cover was the main factor influencing the flow in surface irrigation systems. Accurate values of " $n$ " should be used in designing border irrigation.

However, $n$ values of soil surface are not available under different methods of soil preparation and different conditions of vegetation covers for continuous and surge flow.

Therefore, the aim of this work is to determine the values of Manning roughness coefficient " $n$ " for border irrigation in a clay loam soil with compacted and un-compacted soil under continuous and surge flow.

\section{MATERIAL AND METHODS}

This aim of this work was planned to be realized through two stages:

1- Mathematical analysis was done to predict the Manning roughness coefficient " $n$ ".

2- Field experiments were done in a clay loam soil with compacted and un-compacted soil under continuous and surge flow.

\section{Mathematical analysis}

A scientific approach based mainly on the mathematical analysis was followed in this study. The factors affecting the Manning roughness coefficient " $n$ " were first determined. These factors were then related to the Manning roughness coefficient in a mathematical relationship. 


\subsection{Mathematical analysis approach}

The flow regime in surface irrigation is usually sub critical and the downstream conditions influence the upstream conditions. The finite difference solution begins from the downstream and estimates the upstream flow conditions (Wallender and Rayej, 1990). The roughness at any surface irrigation systems has been expressed often in terms of the Manning roughness coefficient " $n$ " which can be calculated from equation (2):

$$
\begin{aligned}
& Q=\frac{1}{n}\left(A *\left(\frac{A}{P}\right)^{2 / 3} * S^{1 / 2}\right) \\
& n=\frac{\left(A^{5 / 3} * S^{1 / 2}\right)}{\left(Q^{*} P^{2 / 3}\right)} \ldots \ldots \ldots \ldots .
\end{aligned}
$$

For border irrigation, $A$ is the variable flow cross-section area in $\mathrm{m}^{2}, S$ is the border water surface bottom slope in $\mathrm{m}^{-1} \mathrm{~m}^{-1}, Q$ is the flow rate in $\mathrm{m}^{3} \cdot \mathrm{m}^{-1} \mathrm{~s}^{-1}$ and $P$ is the variable wetted perimeter in $\mathrm{m}$.

The hydraulics of unsteady state gradually varying flow in a border can be described by the equations of Saint-Venant (Wallender and Rayej, 1990). The Saint- Venant equations are the well-known partial differential equations of two physical principles: conservation of mass and Newton's second law of motion. These equations have been presented by Chow (1959), Henderson (1966), Strelkoff (1969) and others. In this research, the mass conservation (i.e. continuity equation) for the flow in border was used as the most suitable mathematical analysis approach.

$$
\frac{\partial Q}{\partial x}+\frac{\partial A}{\partial t}+\frac{\partial Z}{\partial t}=\mathbf{O}
$$

Where:

$x=\quad$ The distance to the advancing water front, $\mathrm{m}$;

$Z=\quad$ The volume of infiltrated water per meter length, $\mathrm{m}^{3} \cdot \mathrm{m}^{-1}$;

$t=$ The elapsed time, $\mathrm{s}$. 
Equation (3) is a first-order, non-linear, hyperbolic partial differential equation with no closed form solution. (Bakery et al., 1992). However, numerical solution is possible for border irrigation.

\subsection{Determination of the infiltrated water volume per unit length "Z"}

The infiltrated water volume per unit length "Z" has been commonly represented by Kostiakov equation (James, 1988):

$$
\mathrm{Z}=a \times T^{b}
$$

Where:

$T=$ The time that water has been in contact with the soil "opportunity time", min;

$a$ and $b=$ Kostiakov infiltration constants.

The opportunity time " $T$ " was determined from equation (5) as follows.

$$
T=\mathrm{t}(\mathrm{i})-\mathrm{t}(\mathrm{a})+\mathrm{t}(\mathrm{r}) \text {. }
$$

Where:

$$
\begin{aligned}
& t(i)=\text { The irrigation time, } \min ; \\
& t(a)=\text { The advance time, min; } \\
& t(r)=\text { The recession time, min. }
\end{aligned}
$$

To determine the Kostiakov infiltration constants ( $a$ and $b$ ), the advance methodology has been described by (Benami and Ofen, 1984), on the basis of the advance of the water front. Equation (6) was used in order to obtain the infiltration constants,

$$
(Q T-A x)=Z=a T^{b}
$$

The data of advance and infiltrated volume of water are fitted with a power regression " $Q T-A x$ " versus " $x$ ", where " $Z$ " is the value of water infiltrated volume and equal " $Q T-A x "$ at distance " $x "$.

The advance technique estimates the volume of water on the surface taking into account the average values for the area throughout the length of the run. This methodology assumes that the infiltration characteristics along the border are homogeneous as well as the cross-sectional area of the border. This technique requires several instantaneous measurements 
at different time steps of the advance of the water front. The advance method has the advantage that it may describe accurately the process of infiltration. However, it requires a large amount of field measurements. (Benami and Ofen, 1984).

\subsection{Determination of discharge rate " $Q_{i, j}$ "}

The next step is to calculate the values of discharge rate at different steps of length and time " $Q_{i, j}$ " by using the continuity equation, Eq. (3). The finite difference form (using the forward difference approximation) of Eq. (3), after rearrangement, becomes

$Q_{i, j}=Q_{i-1, j}-\left[\left|\frac{\Delta x}{2} * \frac{\left(A_{i-1, j-1}-A_{i-1, j}+A_{i, j-1}-A_{i, j}\right)}{\Delta t_{j}}\right|+\frac{\Delta x}{2} * \frac{\left(Z_{i-1, j-1}-Z_{i-1, j}+Z_{i, j-1}-Z_{i, j}\right)}{\Delta t_{j}}\right] \ldots \ldots(7)$

Where:

$i=$ The number or position of the grid station along the border.

$j=$ The time-line/ time-step.

$\Delta x=$ The distance between consecutive nodes along the border, known as the distance interval.

$\Delta x=x_{i}-x_{i-1}=$ constant

$\Delta t_{j}=$ The time difference between two consecutive time-lines known as time intervals/increments.

$\Delta t=t_{j}-t_{j-1}$

This study uses a constant value for " $Q_{0}$ " over a known time period t(i) .

\subsection{Determination of Manning roughness coefficient " $n$ "}

The Manning equation [eq. 2] is used to calculate the values of $n$. After transformation into a numerical form , Eq. (2) becomes:

$$
\begin{aligned}
& n_{i, j}=\left[\frac{2}{Q_{i-1, j}+Q_{i, j}}\right] *\left[\frac{A_{i-1, j-1}+A_{i-1, j}+A_{i, j-1}+A_{i, j}}{4}\right]^{5 / 3} *\left[\frac{P_{i-1, j-1}+P_{i-1, j}+P_{i, j-1}+P_{i, j}}{4}\right]^{-2 / 3} \\
& *\left[\left|\frac{D_{i-1, j-1}+D_{i-1, j}+D_{i, j-1}+D_{i, j}}{2 \Delta x}\right|\right]^{1 / 2} \ldots \ldots \ldots \ldots \ldots \ldots \ldots \ldots \ldots \ldots \ldots \ldots \ldots \ldots \ldots \ldots \ldots \ldots \ldots \ldots \ldots \ldots \ldots \ldots \ldots \ldots \ldots \ldots \ldots \ldots \ldots
\end{aligned}
$$

Where:

$$
\begin{aligned}
& P_{i, j}=\text { The wetted perimeter at nodes } i \text { and } j \\
& D_{i, j}=\text { The elevation of water surface at nodes } i \text { and } j .
\end{aligned}
$$


The value for $D$ is obtained by the addition of the elevation of the border bottom to the water depth at each station.

The final value of $n$ is the average of $n_{i, j}$ values as

$$
n=\sum_{i=1}^{m} \sum_{j=1}^{l} n_{i, j} / N
$$

where $\quad N=$ The number of calculated $n_{i, j}$ at nodes $i$ and $j$.

\section{Field experiments}

A field experiment was carried out at the special farm, Qalyubia Governorate during season 2009-2010. Two field plots of the experiment were located on a clay loam soil. Some physical properties of the field soil are determined according to Anter et al. (1987). The soil texture of the field soil was clay loam; the field capacity and the wilting point were found to be $36 \%$ and $13 \%$ weight bases, respectively and the bulk density was $1.42 \mathrm{~g} / \mathrm{cm}^{3}$. The field experiment, fig. (1), was divided into two plots; each plot was $14 \mathrm{~m}$ by $50 \mathrm{~m}$ with uniform longitudinal slopes $0.03 \%$. The first plot for continuous and the second for surge flow respectively. Each plot was divided in two units. In each unit, four borders were established. In the first unit, the soil was tillaged two ways by chisel plow, while in the second unit the soil was tillaged two ways by chisel plow (7 teeth) then compacted with $22.5 \mathrm{kPa}$ soil surface pressure by soil compaction machine shown in fig. (2), this machine was designed and constructed by Kassem and Ghonimy (2001). From the metal cylinder weight and the contact surface area of the required soil compaction pressure was determined and was found to be $22.5 \mathrm{kPa}$. Aggregates size distribution, were determined immediately after the soil compaction using dry sieve technique described by Kepner and Chepil (1960). A set of sieves of 9.53,4.76, 3.18, 1.98, 1.40 and $0.71 \mathrm{~mm}$ diameter were used. The mean weight diameter of the dry aggregates was calculated according to De-Leenheer and De-Boodt (1966). Wheat was planted by seed broadcasting on December 1, 2009, and borders with 1.2 $\mathrm{m}$ width were made for irrigation in all different units.

After seeds were planted, each plot was irrigated then they were irrigated 15 days apart. The water was supplied through a perforated pipe having 
orifices spacing of $0.6 \mathrm{~m}$ apart. The discharge rate of each orifice was measured before beginning the irrigation and it was maintained to $0.55 \mathrm{lit} / \mathrm{s}$ for each orifice. Each border had two orifices with $1.1 \mathrm{lit} / \mathrm{s}$ discharge rates. Before each irrigation, the inflow rate was adjusted to the desired constant inflow rate by volumetric method (given volume at a given time duration) by adjusting the valve. For surge flow the on- time flow was $20 \mathrm{~min}$ and off- time was $20 \mathrm{~min}$.

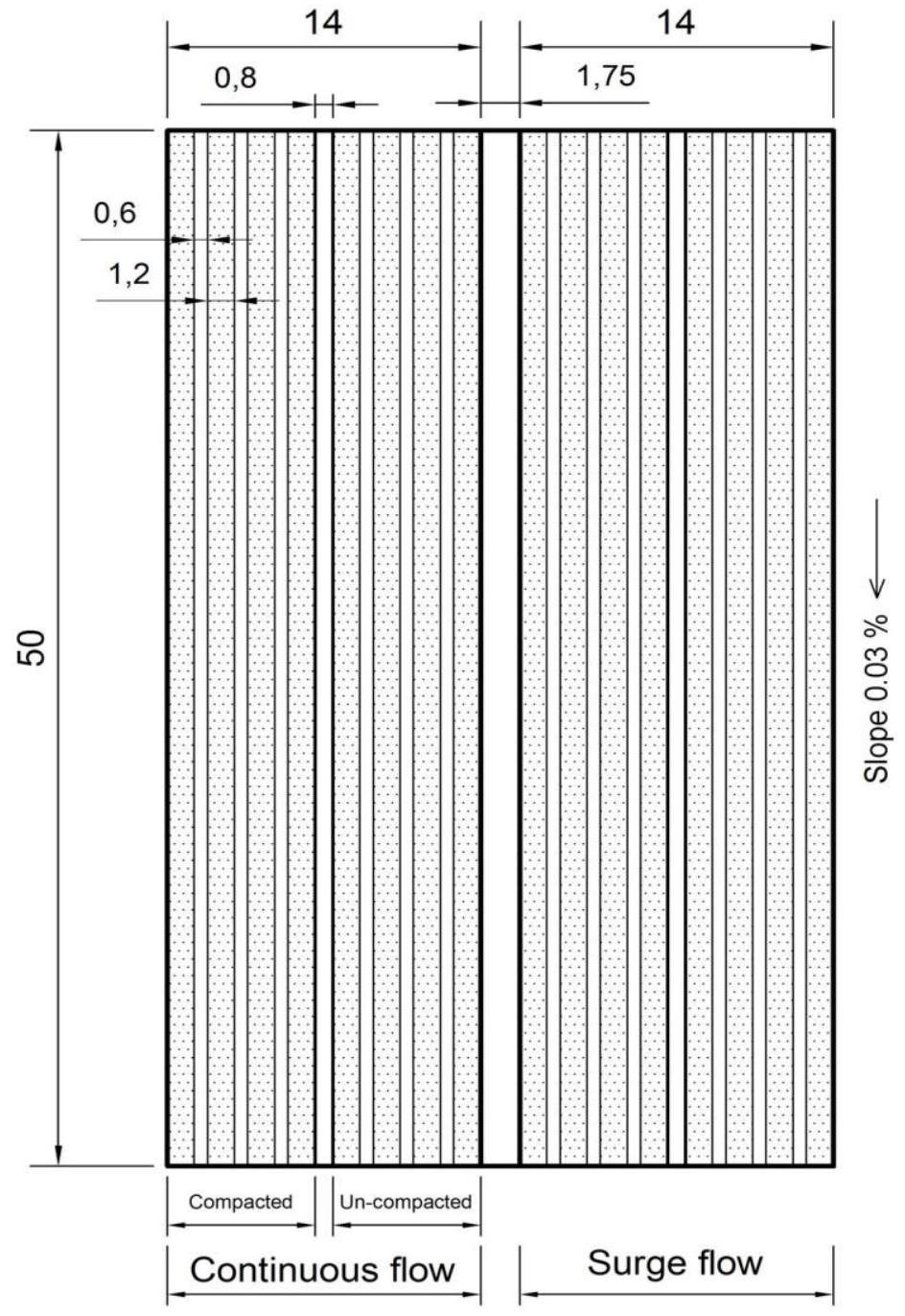

Dimensions in $\mathrm{m}$

Fig. (1): Layout of the field experiment 


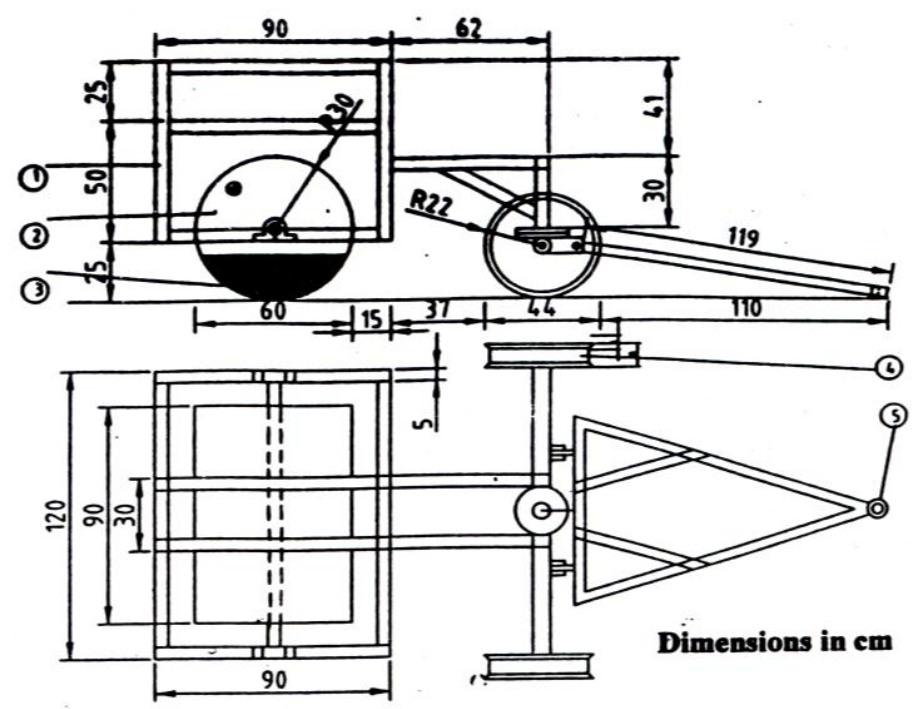

1- Frame 2-Cylinder 3-Water 4-Front wheel 5- Hitching point Fig. (2): The components of the soil compaction machine.

Rulers were penetrated vertically in the bottom of the borders $30 \mathrm{~cm}$ from each side at distances of $10 \mathrm{~m}$ from the beginning of border throughout its length (station). The advancing time of the water front and the recession time were measured at each station. By determining the values of water depth of the flow cross-section at all stations, the flow cross-sections and wetted perimeters were determined (Walker and Skogerboe, 1987). Furthermore, the elevation of the water surface at each station was determined by adding the elevation of the border bottom to the depth of water at each station.

The mean value of $n$ for four borders was calculated for each irrigation number for different treatments. The mean values of $n$ were calculated for sequence seven irrigations. The field was irrigated from December 1, 2009 to March 1, 2010 with an interval of 15 days. Before each irrigation, the vegetation cover percentages in each border were determined by locating a square meter frame on four points along a border. For each point, the numbers of plant inside the frame were determined. Also, for each plot, the diameters of twentieth wheat stem were measured by using vernier caliper (accuracy $= \pm 0.1 \mathrm{~mm}$ ). The 
vegetation cover percentage $(V C P)$ was determined from equation (10) as follows:

$$
V C P=\frac{A_{p} \times N_{p}}{A_{f}} \times 100
$$

Where:

$V C P=$ Vegetation cover percentages, $\%$;

$A_{p}=$ Stem wheat area, $\mathrm{cm}^{2} ;=\frac{\pi}{4} d^{2}$

$d=$ Average stem diameter, $\mathrm{cm} ; 20$ plant per plot were used

$N_{p}=$ Number of plant inside the frame;

$A_{f}=$ Frame cross sectional area $=10000 \mathrm{~cm}^{2}$

\section{RESULTS AND DISCUSSION}

\section{Aggregates size distribution ( $A S D$ ) and mean weight diameter (MWD)}

The aggregates size distribution $(A S D)$ and mean weight diameter $(M W D)$ are shown in table (1). From table (1), it's clear that the average values of aggregates size were $46.43,14.32,3.47,14.83$ and $5.79 \%$ for $(<$ $0.71 \mathrm{~mm}),(0.71-1.40 \mathrm{~mm}),(1.40-1.98 \mathrm{~mm}),(1.98-4.76 \mathrm{~mm}),(4.76-9.53$ $\mathrm{mm})$ and $(>9.53 \mathrm{~mm})$ respectively.

For first layer $(0.0-2.5 \mathrm{~cm})$, the aggregates size distribution $(<0.71 \mathrm{~mm})$ of compacted soil was increased by $18.77 \%$ compared with the uncompacted soil. The same trend was found for aggregate size (0.71-1.40 $\mathrm{mm})$ and $(1.40-1.98 \mathrm{~mm})$. But the aggregate size $(>4.76 \mathrm{~mm})$ was decreased compared with un-compacted soil. The mean weight diameter $(M W D)$ for compacted soil was decreased compared with un-compacted soil. The value of $(M W D)$ for the first soil layer $(0-2.5 \mathrm{~cm})$ was 1.79 $\mathrm{mm}$. Meanwhile, the value of $M W D$ was $3.73 \mathrm{~mm}$ for un-compacted soil. For aggregate size $(1.98-4.76 \mathrm{~mm})$ the effect of compaction pressure on $S A D$ is too limited.

For the second layer $(2.5-5.0 \mathrm{~cm})$, the aggregates size distribution $(<0.71 \mathrm{~mm})$ of compacted soil was increased by $3.07 \%$ compared with the un-compacted soil. Also, the results of aggregate size (0.71-1.40 $\mathrm{mm}),(1.40-1.98 \mathrm{~mm}),(1.98-4.76 \mathrm{~mm})$ and $(4.76-9.53 \mathrm{~mm})$ showed that there is no clear effect of compaction on the aggregates. 
Table (1): Aggregate size distribution $A S D$ and mean weight diameter $M W D$ for compacted and uncompacted.

\begin{tabular}{|c|c|c|c|c|c|c|c|c|c|}
\hline \multirow{3}{*}{$\begin{array}{l}\text { Soil depth } \\
\text { (cm) }\end{array}$} & \multicolumn{8}{|c|}{ Aggregate size distribution $A S D, \%$} & \multirow{3}{*}{$\begin{array}{r}M W D \\
(\mathbf{m m})\end{array}$} \\
\hline & $\begin{array}{l}<0.71 \\
(\mathbf{m m})\end{array}$ & $\begin{array}{c}0.71- \\
1.40 \\
(\mathrm{~mm})\end{array}$ & $\begin{array}{c}1.40- \\
1.98 \\
(\mathrm{~mm})\end{array}$ & $\begin{array}{l}1.98- \\
4.76 \\
(\mathrm{~mm})\end{array}$ & $\begin{array}{c}4.76- \\
9.53 \\
(\mathrm{~mm})\end{array}$ & $\begin{array}{l}>9.53 \\
(\mathrm{~mm})\end{array}$ & $\begin{array}{c}<= \\
1.98 \\
(\mathrm{~mm})\end{array}$ & $\begin{array}{l}>1.98 \\
(\mathrm{~mm})\end{array}$ & \\
\hline & \multicolumn{8}{|c|}{ Un-compacted soil } & \\
\hline $0.0-2.5$ & 38.75 & 11.15 & 3.44 & 14.61 & 14.00 & 18.05 & 53.34 & 46.66 & 3.65 \\
\hline $2.5-5.0$ & 45.50 & 12.54 & 3.57 & 15.42 & 12.63 & 10.34 & 61.61 & 38.39 & 2.89 \\
\hline $5.0-7.5$ & 37.43 & 13.47 & 3.46 & 14.62 & 18.40 & 12.62 & 54.36 & 45.64 & 3.64 \\
\hline Mean & 40.56 & 12.39 & 3.49 & 14.88 & 15.01 & 13.67 & 56.44 & 43.56 & 3.39 \\
\hline \multicolumn{10}{|c|}{ Compacted soil } \\
\hline $0.0-2.5$ & 57.52 & 16.20 & 3.24 & 13.64 & 9.40 & 0.00 & 76.96 & 23.04 & 1.79 \\
\hline $2.5-5.0$ & 48.57 & 12.11 & 2.77 & 15.04 & 16.27 & 5.24 & 63.45 & 36.55 & 2.74 \\
\hline $5.0-7.5$ & 33.21 & 14.66 & 4.39 & 15.80 & 19.80 & 12.14 & 52.26 & 47.74 & 3.63 \\
\hline Mean & 46.43 & 14.32 & 3.47 & 14.83 & 15.16 & 5.79 & 64.22 & 35.78 & 2.72 \\
\hline
\end{tabular}


The value of $M W D$ for the second soil layer $(2.5-5.0 \mathrm{~cm})$ was $2.74 \mathrm{~mm}$, while, the value of $M W D$ for un-compacted soil was $2.89 \mathrm{~mm}$.

For the third $(5.0-7.5)$ layers, results showed that there is no clear effect of the compaction on the soil aggregates.

By comparing the compacted and un-compacted soil, its clear that the $M W D$ of compacted soil decreased by a ratio of 50.96 and $5.19 \%$ for first and second layers respectively compared to the un-compacted soil. Meanwhile, there is no clear effect of the compaction on the $M W D$ at the third layer.

This decrease of $M W D$ caused a decrease of pore spaces, which may have a decreasing both of infiltrated water and Manning roughness coefficient.

\section{Vegetation cover percentages $(V C P)$}

The average values of vegetation cover percentage $(V C P)$ for all treatments of different irrigation numbers are shown in figure (3).

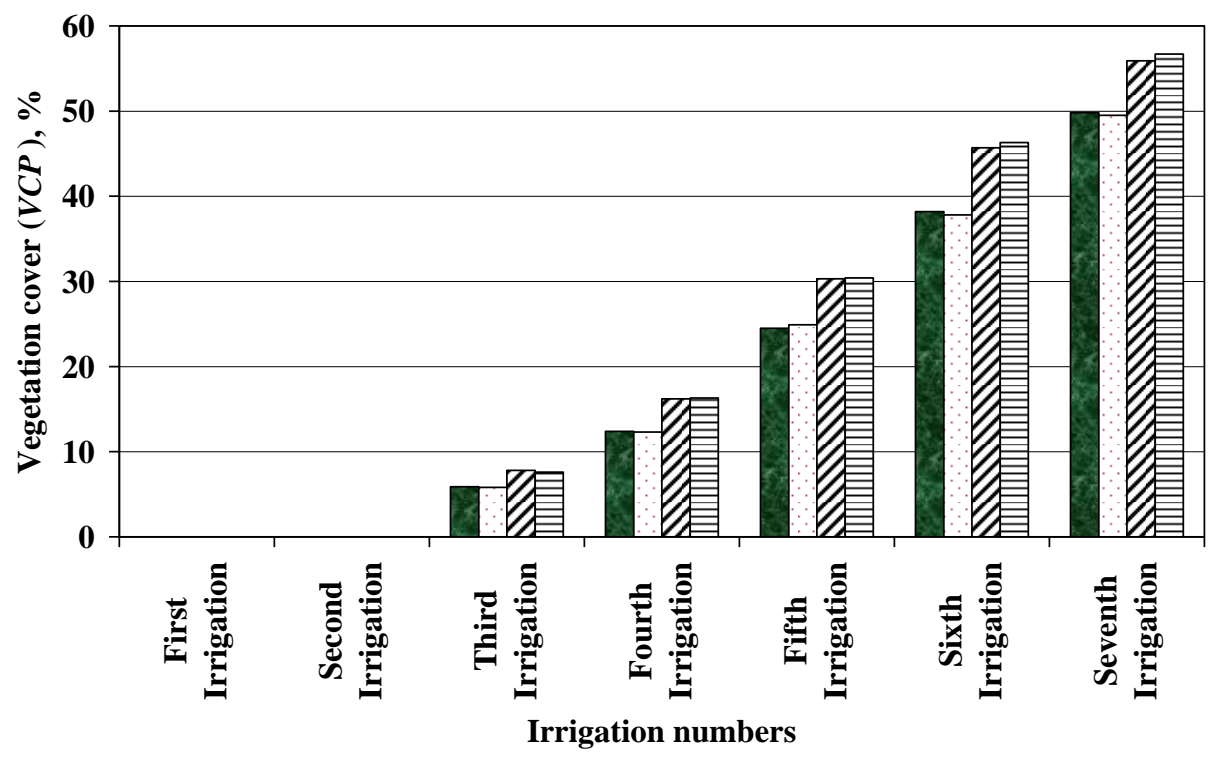

Q C. C.

$\square$ C. U. ES.C. $\boxminus$ S. U.

C.C.= Continuous flow in compacted soil C.U.= Continuous flow in Un-compacted soil
S. C. = Surge flow in compacted soil

S. U.= Surge flow in Un-compacted soil

\section{Fig. (3): Vegetation cover percentages $(V C P)$ of all treatments for different irrigation numbers}

From figure (3) it's clear that the values of vegetation cover percentage $(V C P)$ increased by increasing the irrigation numbers and reached to the 
maximum values at $7^{\text {th }}$ irrigation. The $V C P$ were zero for the first and second irrigations. For continuous flow, the values of VCP increased from 5.9 and $5.8 \%$ for third irrigation to 49.8 and $49.5 \%$ for seventh irrigation for compacted and un-compacted soils respectively. The same trend was found for surge flow at compacted and un-compacted soils. Also, the results indicated that the soil compaction had not any effect on the vegetation cover percentage for continuous and surge flow. The maximum values of $V C P$ were obtained for surge flow for all irrigation numbers.

The increasing of $V C P$ for surge irrigation was due to a higher water distribution uniformity and water application efficiency compared with continuous irrigation (Morcos et al., 1996). While, the minimum values of vegetation cover percentage were obtained for continuous flow for all irrigation numbers.

\section{Infiltrated water volume per unit length $(Z)$}

The infiltrated water volume per unit length $(Z)$ for continuous and surge flow are shown in figures (4 and 5).

For continuous flow (Fig. 4), it's clear that the infiltrated water volume per unit length $(Z)$ decreased for compacted soil compared to uncompacted soil. The soil surface compaction had its highest effect on $\mathrm{Z}$ for first irrigation, while in next irrigations, there are any variations between the compacted and un-compacted soil. The $\mathrm{Z}$ value decreased by $17.51 \%$ for compacted soil compared to un-compacted soil in the first irrigation.

For surge flow (Fig. 5), it's clear that the infiltrated water volume per unit length $(Z)$ decreased for compacted soil compared to un-compacted soil in the first irrigation cycle only for first irrigation. The $\mathrm{Z}$ value decreased by $21.91 \%$ for compacted soil compared to un-compacted soil in the first irrigation cycle for first irrigation. The $Z$ values for compacted soil are too close to the un-compacted soil in all irrigation cycle and irrigation numbers after the first irrigation cycle. 
The decreasing of infiltrated water volume per unit length for compacted soil was due to the decreasing of mean weight diameter caused a decrease of pore spaces of the first layer of soil surface.

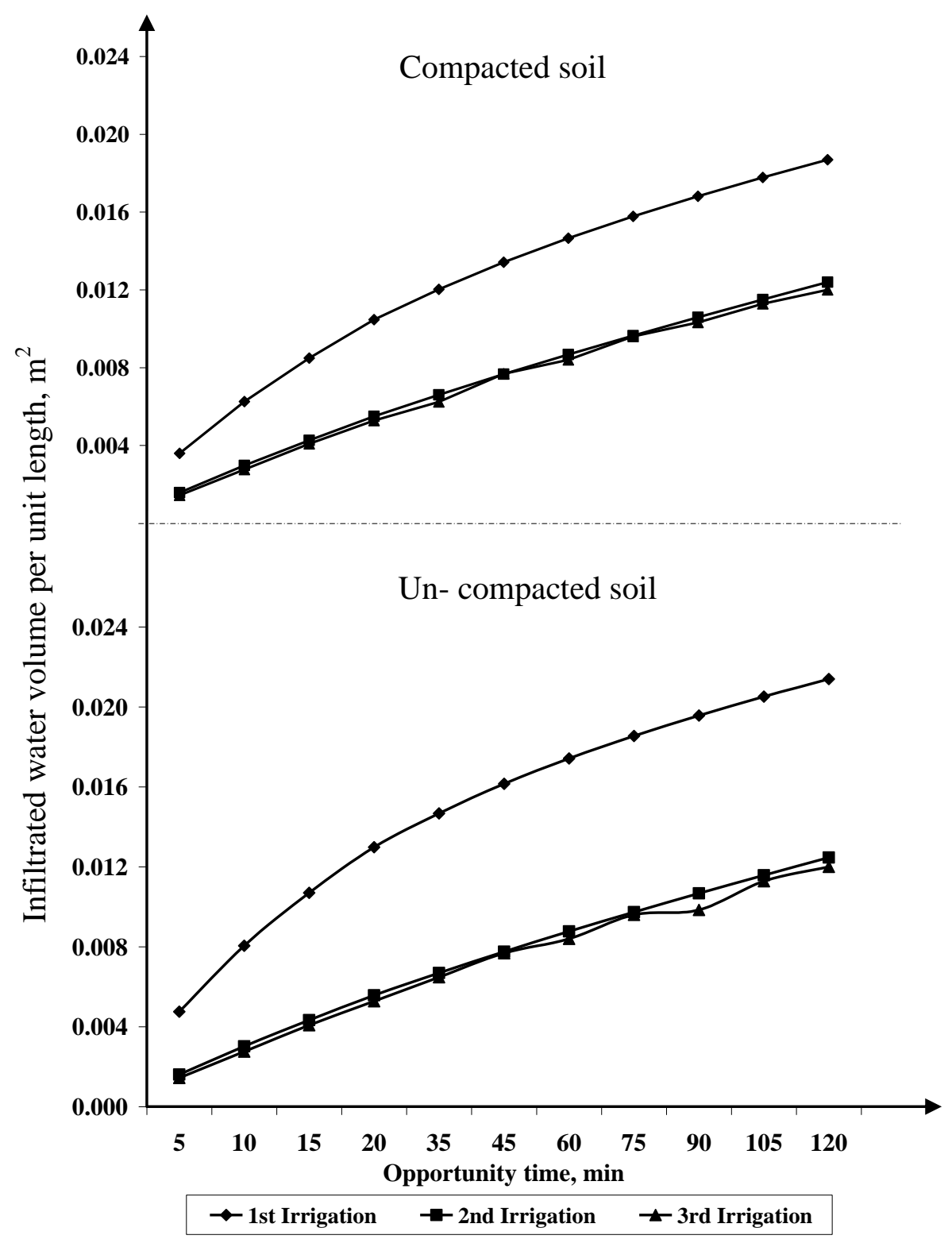

Fig. (4): Infiltrated water volume per unit length of compacted and un-compacted soil for continuous flow 


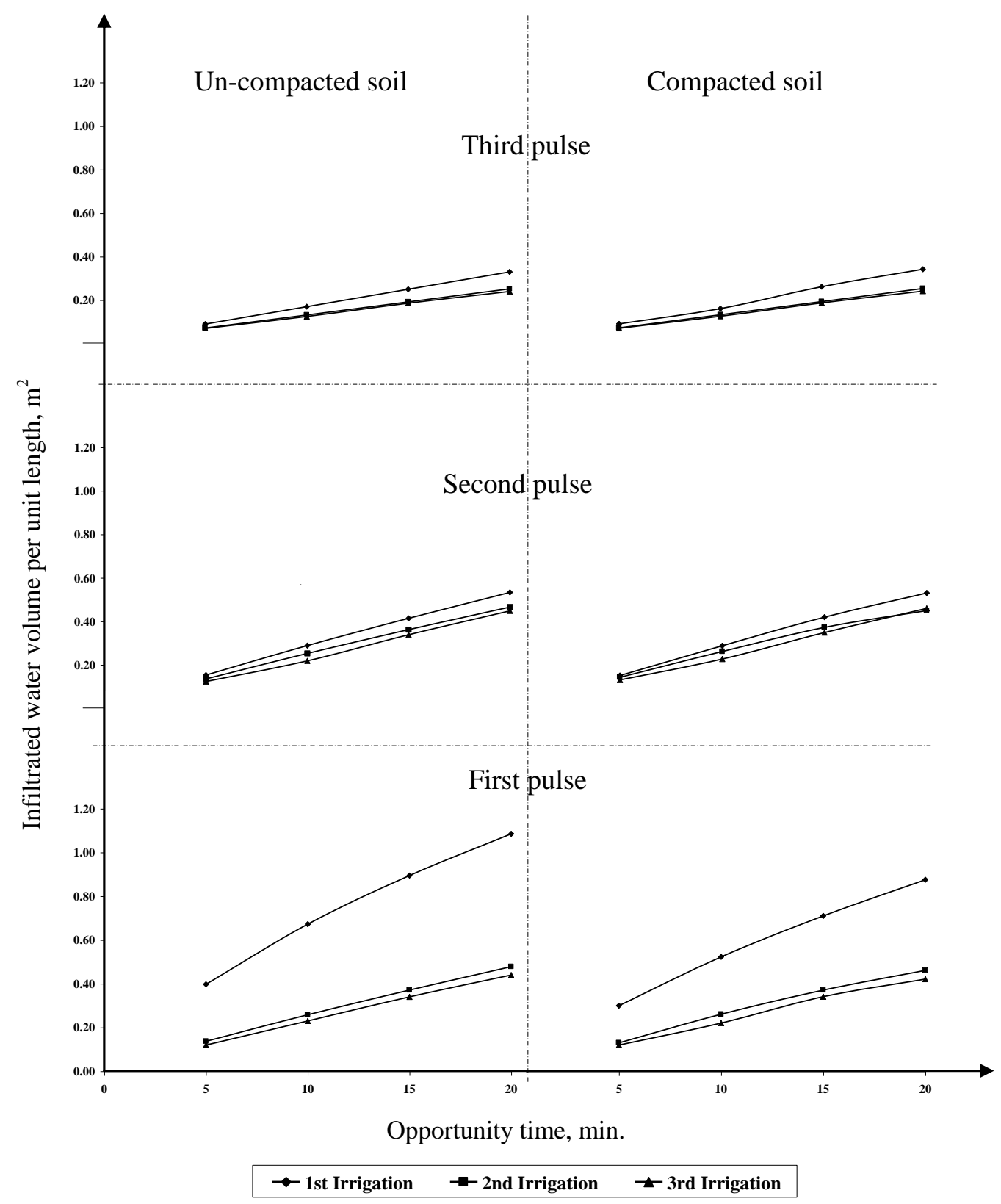

Fig. (5): Infiltrated water volume per unit length of compacted and un-compacted soil for surge flow 
4. Manning roughness coefficient values " $n$ " of border soil surface without crop for continuous flow.

The average values of infiltration constants " $a$ and $b$ " and Manning roughness coefficient " $n$ " for border soil surface without crop for continuous flow are shown in table (2). The results indicated that the mean values of Manning roughness coefficient for un-compacted soil surface were 0.1915 for the first irrigation and 0.0961 for the second irrigation. So, the Manning roughness coefficient value for second irrigation was decreased by $49.82 \%$ compared to the first irrigation for un-compacted soil with continuous flow. Similar results were reported by Trout (1992) in which the value of " $n$ " in the border for the first irrigation was twice that for the second irrigation for clay loam soil.

Table (2): The values of Manning roughness coefficient and infiltration constants of border soil surface without crop for continuous flow

\begin{tabular}{||c|c|c|c|c||}
\hline \multirow{2}{*}{ Treatments } & \multirow{2}{*}{$\begin{array}{c}\text { Infiltration } \\
\text { constants }\end{array}$} & \multirow{2}{*}{$\begin{array}{c}\text { Manning } \\
\text { roughness } \\
\text { coefficient }\end{array}$} \\
\hline \multirow{2}{*}{ Un-compacted soil } & 1 & 0.2480 & 0.4293 & 0.1915 \\
\cline { 2 - 4 } & 2 & 0.0636 & 0.5968 & 0.0961 \\
\hline Compacted soil & 1 & 0.1740 & 0.4743 & 0.1640 \\
\cline { 2 - 4 } & 2 & 0.0618 & 0.6015 & 0.0910 \\
\hline
\end{tabular}

For compacted soil, the values of Manning roughness coefficient were 0.1640 and 0.0910 for the first and the second irrigations respectively. So, the Manning roughness coefficient value for second irrigation was decreased by $44.51 \%$ compared to the first irrigation for compacted soil with continuous flow. By comparing the results of Manning roughness coefficient for compacted and un-compacted soils, it's clear that soil surface compaction had its highest effect on Manning roughness coefficient for first irrigation. The decreasing of $n$ value for compacted soil was due to the decreasing of mean weight diameter of the first layer of soil surface. 
Sepaskhah and Bondar, 2002 found that the values of Manning roughness coefficient $" n$ " for furrow irrigation was 0.041 for the first irrigation with inflow rate of $0.4 \mathrm{lit} / \mathrm{s}$ and about 0.025 for the next irrigations. Therefore, the values of $n$ for border irrigation were almost fourth of those for furrow irrigation due to larger height of water flow in the furrow. In general, the values of $n$ for the first irrigation are larger than those for the next irrigation for furrow and border irrigation due to the undulating surface.

\section{Manning roughness coefficient values for border soil surface without crop for surge flow.}

Three cycles of intermittent irrigation (cycle inflow time $t_{\text {on }}=20 \mathrm{~min}$, offtime $t_{\text {off }}=20 \mathrm{~min}$ ) were carried out on a border. The average values of infiltration constants " $a$ and $b$ " and Manning roughness coefficient " $n$ " for border soil surface without crop for surge flow are shown in table (3). The results indicated that the average values of Manning roughness coefficient for un-compacted soil for first irrigation were 0.192, 0.130 and 0.095 during the first, second and third irrigation cycle numbers respectively, while they were $0.097,0.081,0.073$ for second irrigation during the first, second and third irrigation cycle numbers respectively. For compacted soil, the average values of Manning roughness coefficient for first irrigation were $0.165,0.125$ and 0.093 during the first, second and third irrigation cycle numbers while they were $0.096,0.083$ and 0.076 for second irrigation during the first, second and third irrigation cycle numbers respectively. By comparing the results of Manning roughness coefficient for compacted and un-compacted soils for surge flow, it's clear that soil surface compaction had its highest effect on Manning roughness coefficient values for first irrigation cycle of first irrigation.

The highest $n$ value is encountered during the first irrigation cycle. These $n$ values became smaller during the second irrigation cycle and again smaller during the third one. This is because the watering led the loose topsoil wet and clods dissolved, at the same time, the interval between each of two irrigation events made the topsoil structure much denser and smoother than normal. (Morcos et al., 1996) 
Table (3): The values of Manning roughness coefficient and infiltration constants of border soil surface without crop for surge flow for three irrigation cycles

\begin{tabular}{|c|c|c|c|c|c|c|}
\hline \multirow{2}{*}{ Treatments } & \multirow{2}{*}{$\begin{array}{c}\text { Irrigation } \\
\text { number }\end{array}$} & \multirow{2}{*}{$\begin{array}{l}\text { Cycle } \\
\text { number }\end{array}$} & \multicolumn{2}{|c|}{ Infiltration constants } & \multicolumn{2}{|c|}{$n$} \\
\hline & & & $a$ & $b$ & Value & Average \\
\hline \multirow{6}{*}{ 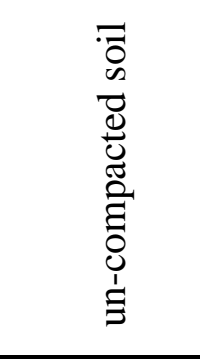 } & \multirow{3}{*}{1} & 1 & 0.1243 & 0.7268 & 0.192 & \multirow{3}{*}{0.139} \\
\hline & & 2 & 0.0367 & 0.8955 & 0.130 & \\
\hline & & 3 & 0.0199 & 0.9363 & 0.095 & \\
\hline & \multirow{3}{*}{2} & 1 & 0.0321 & 0.9024 & 0.097 & \multirow{3}{*}{0.088} \\
\hline & & 2 & 0.0330 & 0.8859 & 0.089 & \\
\hline & & 3 & 0.0167 & 0.9030 & 0.077 & \\
\hline \multirow{6}{*}{ 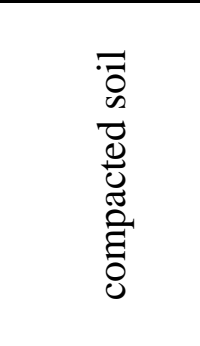 } & \multirow{3}{*}{1} & 1 & 0.0867 & 0.7739 & 0.165 & \multirow{3}{*}{0.128} \\
\hline & & 2 & 0.0328 & 0.9271 & 0.125 & \\
\hline & & 3 & 0.0184 & 0.9692 & 0.093 & \\
\hline & \multirow{3}{*}{2} & 1 & 0.0287 & 0.9330 & 0.096 & \multirow{3}{*}{0.085} \\
\hline & & 2 & 0.0351 & 0.8529 & 0.083 & \\
\hline & & 3 & 0.0167 & 0.9030 & 0.076 & \\
\hline
\end{tabular}

\section{Manning roughness coefficient values for border soil surface with wheat crop for continuous flow}

When wheat grows up, Manning roughness coefficient " $n$ " is influenced not only by the soil surface but also by the crop. As mentioned before (section 4), the soil surface compaction had its effect on Manning roughness coefficient values " $n$ " for first irrigation only. So, the mean values of Manning roughness coefficient " $n$ " for un-compacted and compacted soil surface were calculated, the values of $n$ for different vegetation covers percentage for five irrigations, (from $3^{\text {rd }}$ to $7^{\text {th }}$ irrigation) for continuous flow are shown in table (4). The results indicated that the mean values of soil Manning roughness coefficient for compacted and un-compacted soil were increased by increasing the values of vegetation cover percentages. The value of Manning roughness coefficient $" n "$ increased from 0.11 for third irrigation at $5.85 \%$ 
vegetation cover percentage to 0.25 at $49.65 \%$ vegetation cover percentage for seventh irrigation. So, by increasing the $V C P$ in the borders, the values of $n$ increased. The values of the Manning roughness coefficient " $n$ " varied directly with $V C P$ in borders.

The relationship between the mean values of the Manning roughness coefficient " $n$ " for compacted and un-compacted soil and vegetation cover percentage $(V C P)$ was found to be a linear relation and can be obtained from equation (11) for continuous flow.

$$
n=0.0029 V C P+0.1051
$$

$\mathrm{R}^{2}=0.92$

Table (4): The mean values of Manning roughness coefficient of border soil surface with wheat crop for continuous flow

\begin{tabular}{|c|c|c|c|c|c|}
\hline Irrigation number & $\mathbf{3}$ & $\mathbf{4}$ & $\mathbf{5}$ & $\mathbf{6}$ & $\mathbf{7}$ \\
\hline Vegetation cover $(\boldsymbol{V C P}), \boldsymbol{\%}$ & 5.85 & 12.35 & 24.7 & 38 & 49.65 \\
\hline Manning roughness coefficient & 0.11 & 0.15 & 0.19 & 0.21 & 0.25 \\
\hline
\end{tabular}

\section{Manning roughness coefficient values for border soil surface with wheat crop for surge flow.}

As mentioned before the soil surface compaction had its highest effect on Manning roughness coefficient values " $n$ " for first irrigation cycle for first irrigation, table (3). So, the mean values of Manning roughness coefficient $" n "$ for un-compacted and compacted soil surface were calculated, the values of $n$ for different vegetation covers percentage for five irrigations, (from $3^{\text {rd }}$ to $7^{\text {th }}$ irrigation) for continuous flow are shown in table (5). The results indicated that the mean values of Manning roughness coefficient were increased by increasing the values of vegetation cover percentage. The value of Manning roughness coefficient $" n "$ increased from 0.09 at $7.7 \%$ VCP for third irrigation to 0.21 at $56.3 \%$ $V C P$ for seventh irrigation.

The relationship between the values of the Manning roughness coefficient $" n "$ and the percentage of $V C P$ was found to be a linear relation and can be obtained from equation (12) for surge flow.

$$
n=0.0025 V C P+0.0709
$$

$$
\mathrm{R}^{2}=0.89
$$


Table (5): Manning roughness coefficient values of border soil surface with wheat crop for surge flow

\begin{tabular}{|c|c|c|c|c|c|}
\hline Irrigation number & $\mathbf{3}$ & $\mathbf{4}$ & $\mathbf{5}$ & $\mathbf{6}$ & $\mathbf{7}$ \\
\hline Vegetation cover $(\boldsymbol{V C P}), \boldsymbol{\%}$ & 7.7 & 16.25 & 30.35 & 46 & 56.3 \\
\hline Manning roughness coefficient & 0.09 & 0.11 & 0.15 & 0.19 & 0.21 \\
\hline
\end{tabular}

By comparing the results in tables 4 and 5 its clear that surge flow decreased the values of Manning roughness coefficient " $n$ " with wheat crop than those for continuous flow.

\section{CONCLUSION}

From this investigation, the following conclusion can be made:

1. For continuous flow in border without vegetation cover, soil surface compaction had its effect on Manning roughness coefficient values $" n "$ for first irrigation only. At first irrigation, the values of $n$ were 0.1915 and 0.164 for un-compacted and compacted soils respectively. At the second irrigation, the values of $n$ decreased by about $44.5 \%$ and $49.84 \%$ than those for first irrigation for compacted and uncompacted soil respectively.

2. For surge flow in border without vegetation cover, soil surface compaction had its effect on Manning roughness coefficient values for first irrigation cycle only for first irrigation. The highest $n$ value is encountered during the first irrigation cycle. These $n$ values became smaller during the second irrigation cycle and again smaller during the third one.

3. The maximum values of vegetation cover percentage were obtained for surge flow for all irrigation numbers. While, the minimum values of vegetation cover percentage were obtained for continuous flow for all irrigation numbers

4. For continuous flow in border with wheat vegetation cover, the mean values of $n$ were increased by increasing the values of $V C P$. The $n$ value increased from 0.11 for third irrigation at $5.85 \% V C P$ to 0.25 at $49.65 \% V C P$ for seventh irrigation. The relationship between the $n$ values and $V C P$ was found as follows

$$
n=0.0029 V C P+0.1051 \quad \mathrm{R}^{2}=0.92
$$


5. For surge flow in border with wheat vegetation cover, the value of $n$ increased from 0.09 at $7.7 \% V C P$ for third irrigation to 0.21 at $56.3 \% V C P$ for seventh irrigation. The relationship between the $n$ values and "VCP" was found as follows.

$$
n=0.0025 V C P+0.0709 \quad \mathrm{R}^{2}=0.89
$$

6. Surge flow decreased the values of Manning roughness coefficient " $n$ " for border irrigation without vegetation covers or with wheat crop than those for continuous flow.

\section{REFERENCES}

Anter, I. , M. Negmand and M. I. Mecheal. 1987. Analysis methods of agricultural soils. Soil and Water Res. Inst.Agric.Res.Center., Tech. Report (8):1-22.

Bakery, M. F., T. K. Gater and A. F. Khattab. 1992. Field measured hydraulic resistance characteristics in vegetation infested canals. Journal of Irrigation and Drainage Engineering, 118, 256-274.

Benami, A. and A. Ofen. 1984. Irrigation Engineering: Sprinkler, Trickle, Surface Irrigation. Principles, Design and Agricultural Practices. Irrigation Engineering Scientific Publication, IIIC Bet Dagan, Israel.

Chow, V. T. 1959. Open Channel Hydraulics, 680 pp. McGraw-Hill, New York.

De-Leenheer, L. and M. De-Boodt 1966. Soil physics. International training center for post graduate soil scientist, Ghent, Belgium.

Gilley, J. E. and S. C. Finkner. 1991. Hydraulic roughness coefficients as affected by random roughness. Transactions of the ASAE, 34, 897903.

Henderson, F. M. 1966. Open Channel Flow, 522pp. Macmillan, New York

James, L. C. 1988. Principles of Farm Irrigation System Design. New York. Willey:230p.

Kassem, M. A. and M. I. Ghonimy. 2001. The effect of soil compaction on soil physical properties, the cumulative infiltration rate and the seeds germination. Misr J. Ag. Eng., 18 (2): 222 - 242.

Kepner, W. D. and W. S. Chepil. 1960. Size distribution of aggregate. In C. A. Black et al. Method of soil analysis part 1. Agronomy. 9: 499-510. 
Morcos, M. A., M. A. Abou Zaid and M. A. kassem. 1996. The reliability of the mathematical models for long borders and long furrows applying surge technique. Misr J. Ag. Eng, Cairo Univ.Irr.Conf.,3-4 April : 465-501.

Sepaskhah, A.R. and H. Bondar. 2002. Estimation of Manning roughness coefficient for bare and vegetated furrow irrigation. Journal of Biosystems Engineering 82 (3), 351-357.

Strelkoff, T. 1969. One-dimensional equations of open channel flow. Journal of Hydraulics, American Society of Civil Engineering, 95, 861-876.

Trout, T. J. 1992. Furrow flow velocity effect on hydraulic roughness. Journal of Irrigation and Drainage Engineering, 118, 981-987.

Valiantzas, J. D. 1994. Simple method for identification of border infiltration and roughness characteristics. Journal of Irrigation and Drainage Engineering, 120, 233-249.

Walker, W. R. and G. V. Skogerboe. 1987. Surface Irrigation: Theory and Practice, 386pp. Prentice Hall, Inc., Englewood Cliffs, NJ.

Wallender, W. W. and M. Rayej. 1990. Shooting method for SaintVenant equation of furrow irrigation. Journal of Irrigation and Drainage Engineering, 116, 114-121.

\section{الملخص العربى}

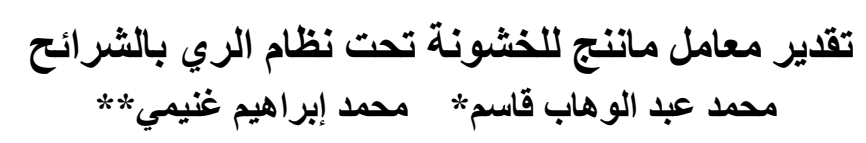

تهدف هذه الدر اسة إلي تقدير معامل مانتج للخشونة لتربة طينية طمييه تحت نظام الري بالثنر ائح و ذللك لطريقتين من طرق تدفق المياه (تدفق مستمر - تدفق نبضي) وطريقتين لتجهيز سطح التربـة (كبس سطح التربة- بدون كبس سطح ملتف التربة). ولتحقيق هذا الهدف تم إجراء الدراسة على مرحلتين:

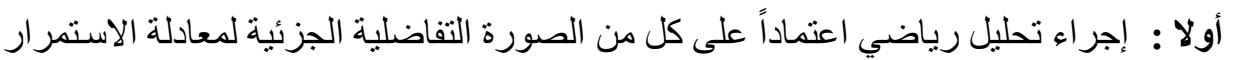

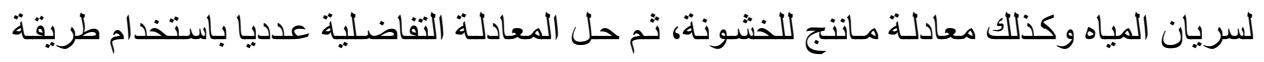

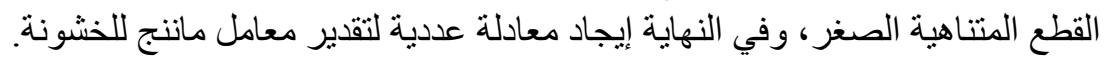

* أستاذ مساعد بقسم الهندسة الزراعية_ كلية الزراعةــ جامعة القاهرة.

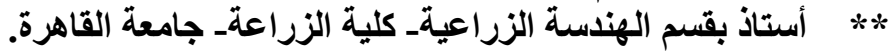




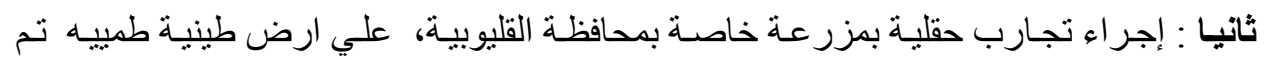

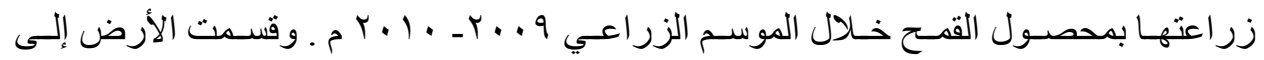

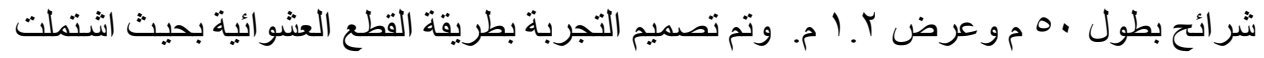
على معاملتين رئيسيتين لتدفق المياه وهما التدفق المستمر و التدفق النبضـي كمـا شملت معاملتين

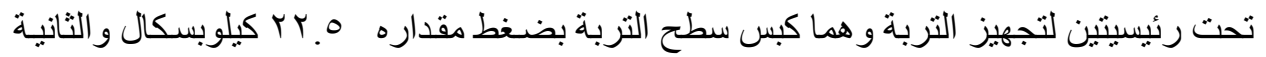
عدم كبس التربة.

\section{وقد أظهرث النتائج ما يليى : و}

\section{ا . . عند استخدام طريقة التدفق المستمر:}

أ. تأثثر كبس سطح التربـة على قيم معامل مـانتج للخشـونة تكون للريـة الأولـي فقط ولا يتضح أي تأثثر لها في الريات التالية.

ب. قيم معامل مانتج للرية الأولي ع 1 . . ـ 19 19 • لمعاملات كبس سطح التربة وبدون

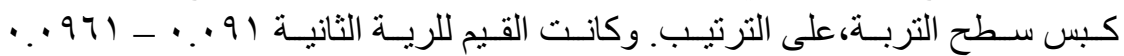
لمعاملات كبس سطح التربة وبدون كبس سطح التربة على الترنيب.

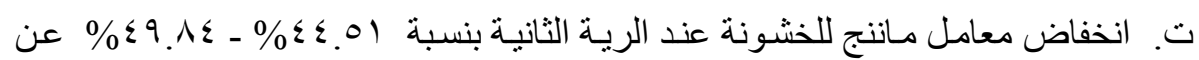
الرية الأولي لمعاملات كبس سطح التربة وبدون كبس سطح التربة، على الترثيب. ث. تزداد قيم معامل ماننج من ا ( . إلى هץ . • (من الرية الثالثة للسابعة) نتيجة زيادة نسبة

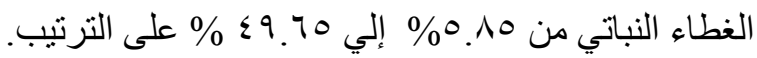

\section{r}

أ. تأثير كبس سطح التربـة على قيم معامل مـانتج للخشونة تكون للنبضـة الأولي بالريـة

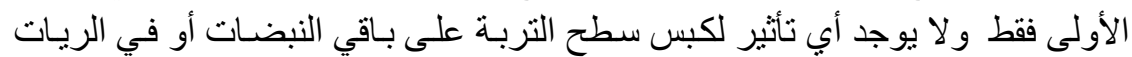
التالية.

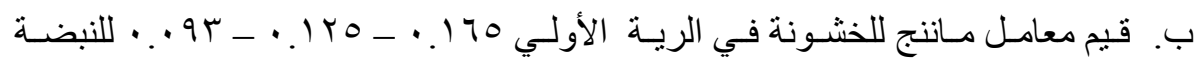

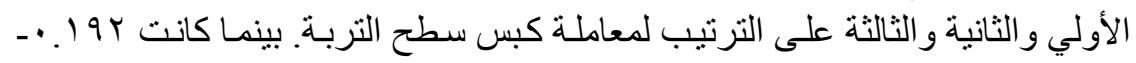

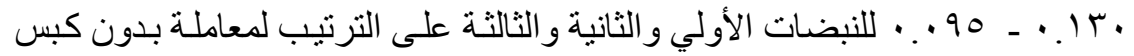

$$
\text { سطح التربة. }
$$

ت. تأثير الري النبضي على قيم معامل ماننج أعلى بكثير من تاثير كبس سطح التربة.

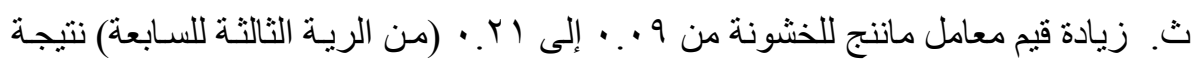

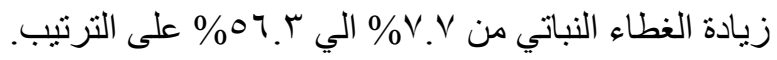

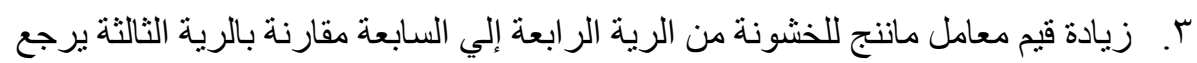
إلي تأثير الغطاء النباتي. ء. تقل قيم معامل مانتج عند استخدام الري النبضـي عن القيم المنـاظرة في حالة استخدام الري المستمر تحت نفس الظروف من نسبة الغطاء النباتي. 